\title{
Cetacean community off French Guiana
}

\author{
Claire Pusineri $1^{1,}$, Ludivine Martinez ${ }^{2}$, Amandine Bordin ${ }^{3}$, Benjamin de Montgolfier ${ }^{1,4}$, Ophélie Deffes ${ }^{4}$, \\ Vincent Rufray ${ }^{5,3}$, Paul Lenrume ${ }^{5}$, Morjane Safi ${ }^{1,4}$, Alessandra Suardi ${ }^{2}$, Virginie Wyss ${ }^{2}$, Dinis Geraldes ${ }^{2}$, \\ Mathieu marzelière ${ }^{2}$, Brendan Leclerc ${ }^{2,6}$, Stephanie Barnicoat ${ }^{7}$ and Renato Rinaldi ${ }^{8}$ \\ 1Ocean Science \& Logistic (OSL), 4 c/o TOTEM, 4 cité Oyana, 97300 Cayenne, French Guiana \\ ${ }^{2} \mathrm{COHABYS}$, Institut du Littoral et de l'Environnement, 2 rue Olympe de Gouges, 17000 La Rochelle, France \\ ${ }^{3}$ GEPOG, 431 route d'Atilla Cabassou 97354 Rémire-Montjoly, French Guiana \\ ${ }^{4}$ Aquasearch, ZAC Les Coteaux, 97228 Sainte-Luce, Martinique \\ ${ }^{5}$ Biotope, 30 Domaine du Montabo, Cayenne 97300, French Guiana \\ ${ }^{6}$ Comité Régional des Pêches Maritimes et des Elevages Marins de Guyane, Port du Larivot, 97351 Matoury, French Guiana \\ ${ }^{7}$ Seiche Limited, 36 Langdon road, Bradworthy Holsworthy Devon EX22 7SF, United Kingdom \\ ${ }^{8}$ Association Evasion Tropicale, rue des Palétuviers, 97125 Pigeon Bouillante, Guadeloupe
}

*Corresponding author: claire.pusineri@gmail.com

\section{Abstract}

Although human activities are developing in French Guiana Exclusive Economic Zone (EEZ) and surrounding countries, knowledge on diversity and ecology of cetaceans in the region is scarce. This study aimed to collect new information on the cetacean species occurring year-round in the entire French Guiana EEZ by combining visual and acoustic data obtained from three boat-based campaigns conducted by local NGOs. The GEPOG campaign was conducted from July 2011 to June 2012, four days every two months; the COHABYS campaign was performed five days per month from January to May 2018; the OSL campaign consisted in four 10-day surveys conducted in June, July, September and October 2018. The visual observation effort conducted when Beaufort sea state $<5$ was $1,961 \mathrm{~km}, 1,491 \mathrm{~km}$ and 3,243 km respectively. Acoustic records were done when Beaufort sea state $<5$ during daylight and/or nighttime, depending on the survey. A total of 132 cetacean sightings were done. Five cetacean families and 15 species were identified. Delphinidae was the family most frequently sighted ( $91 \%$ to $100 \%$ of groups and $99 \%$ to $100 \%$ of individuals per campaign). The most frequent species in the

Keywords: South America, conservation, diversity, boat-based campaigns, marine mammals

\section{ARTICLE INFO}

Manuscript type: Article

\section{Article History}

Received: 31 August 2020

Received in revised form: 25 May 2021

Accepted: 10 June 2021

Available online: 30 September 2021

Responsible Editor: Federico Riet Sapriza

\section{Citation:}

Pusineri, C., Martinez, L., Bordin, A., Montgolfier, B., Deffes, O., Rufray, V., Lenrume, P., Safi, M., Suardi, A., Wyss, V., Geraldes, D., Marzelière, M., Leclerc, B., Barnicoat, S. and Rinaldi, R. (2021) Cetacean community off French Guiana. Latin American Journal of Aquatic Mammals 16(1): 12-22. https://doi.org/10.5597/lajam00266 area were identified, along with their distribution and phenology: Guiana dolphin (Sotalia guianensis) was found in the coastal area (0-20 $\mathrm{m})$, the long-beaked common dolphin (Delphinus delphis) was sighted on the shelf (20-100 m), along with the bottlenose dolphin (Tursiops truncatus) and the Atlantic spotted dolphin (Stenella frontalis) that were also common on the upper slope (100-1,500 m). Finally, the spinner dolphin (Stenella longirostris), the melon-headed whale (Peponocephala electra) and the pantropical spotted dolphin (Stenella attenuata) were frequent on the slope $(100-3,500 \mathrm{~m})$. The results suggest these species may be found in French Guiana waters all year round and mother and calf pairs, as indicator of reproduction, were observed for all of them except the long-beaked common dolphin and the Guiana dolphin. Mother and calf pairs of humpback whales (Megaptera novaeangliae), that potentially belong to the "A" stock, were also sighted twice, as well as two groups of sperm whales (Physeter macrocephalus) with calves. Hence, these results showed that French Guiana bears a particular responsibility for the conservation of cetacean biodiversity, but a lot remains to be done to strengthen knowledge and conservation of these species in the territory.

\section{Introduction}

French Guiana is a French tropical overseas territory situated along the northern coast of South America. Its Exclusive Economic Zone (EEZ; $4-9^{\circ} \mathrm{N}, 49-54^{\circ} \mathrm{W}$ ), spanning $132,000 \mathrm{~km}^{2}$, extends $200 \mathrm{~nm}$ into the Atlantic Ocean. It includes a wide continental shelf, a continental slope and an abyssal plain where depths approach 4,500 m. French Guiana, Suriname, Guyana, Southern Venezuela, and North Brazil (Amapá state) are referred to as the Guianas. Compared to other tropical regions, these Guiana waters are characterized by a relatively high and seasonal productivity owing to river discharge, in particular from the Amazon River (Longhurst, 2007). Three areas within the French Guiana EEZ have been qualified as Key Biodiversity Areas, i.e. "sites contributing significantly to the global persistence of biodiversity" (Roger et al., 2016): two are situated on the coastal and continental shelf habitats and the third one is located on the slope. This classification was mainly based on the fact that these areas are 
major reproduction and feeding sites for several species of sea turtles, marine mammals and seabirds.

However, these areas are not free from human impacts. Bycatch in fishing nets was found to be a major concern for the Guiana dolphin (Sotalia guianensis) and sea turtles (IUCN France et al., 2017). Local release of contaminants from land mining activities in coastal water is also an issue especially for top predators, with high mercury concentrations found in several nesting seabird species (Sebastiano et al., 2017). The development of oil activities in the Guianas has also been identified as a threat in the Key Biodiversity Areas documents (Roger et al., 2016). The poor results of the latest exploratory drilling conducted off French Guiana in 2018 and the recent (2017) French legislation that prohibits new delivery of exploratory permits in French territories put an end to the development of oil activities in French Guiana EEZ. However, these activities are still numerous in neighboring countries and could have an impact on the local marine environment in case of an oil spill. In French Guiana, as in all French territories, cetaceans are fully protected by order of 3 September 2020 (i.e., destruction, mutilation, capture, and intentional disturbance are prohibited). However, until recently, knowledge on cetaceans in French Guiana was very weak and insufficient to ensure the protection of the species and in particular to assess impacts of human activities identified as threats.

The first cetacean-dedicated program conducted off French Guiana was an aerial campaign performed in October 2008 all over the EEZ to monitor the large pelagic fauna (Mannocci et al., 2013). Seven cetacean species were identified, including fin whale (Balaenoptera physalus), the sperm whale (Physeter macrocephalus), Cuvier's beaked whale (Ziphius cavirostris), and five delphinids, which were found to strongly dominate the community. The bottlenose dolphin (Tursiops truncatus) was the most frequently sighted species in all habitats, except the coastal area, where the second most abundant species, the Guiana dolphin was mainly sighted. These campaigns were effective regarding the monitoring of the main taxonomic groups and provided information on the community composition; however, species identification was limited from planes and they could not account for seasonal variability because surveys were conducted only in October. In subsequent years, opportunistic data were collected by marine mammal observers during seismic oil exploration campaigns conducted on the continental slope area ${ }^{1,2}$. These data provided information regarding the diversity of cetacean species: 17 species were identified during these campaigns, including three balaenopterids, the sperm whale, Cuvier's beaked whale, and 12 delphinids. Delphinids strongly dominated the community, and the spinner dolphin (Stenella longirostris) was the most frequently sighted species in both studies. The humpback whale (Megaptera novaeangliae) was sighted for the first time during these surveys: a mother and calf pair was observed at the end of $2009^{2}$ and seven sightings, including three mother-calf pairs were collected from August to November 2012 1 . In October and November 2017, Martinez et al. (2019) opportunistically collected cetacean sightings during an oceanographic survey conducted on the continental slope. Seven species were identified, including the humpback whale, the sperm whale, and five delphinids. Delphinidae was the most common family but the most frequently sighted species was the humpback whale.

All these boat-based opportunistic studies significantly improved knowledge on cetacean diversity in French Guiana EEZ; however, these data are limited to specific areas and periods and the variety of protocols and platforms they used make them difficult to compare.

In order to further build knowledge on cetacean species occurring in French Guiana EEZ, in view of improving future impact assessments, we combined visual and acoustic data obtained from three cetacean-dedicated boat-based campaigns conducted in 2011-2012 and then in 2018. This study aims to determine species diversity, the presence of vulnerable species (i.e., species listed in IUCN Red List as well as migrating and endemic species), and identify dominant species, occurring within French Guiana EEZ.

\section{Material and methods}

\section{Study area}

French Guiana waters are influenced by the turbid freshwater discharge from the Amazon River (Hu et al., 2004) which reaches its maximum in May-June and minimum in November (Lentz, 1995). The river plume is carried northwest by the North Brazil Current and its extension, the Guiana Current. These currents curl offshore, in what is known as a retroflection, from June through December (Hu et al., 2004). Consequently, productivity varies seasonally and is at its highest as well as most extended offshore during late spring-early summer (May-August; Hu et al., 2004). Wind and wave patterns in the area are dominated by north-eastern trade winds. The EEZ can be divided into four habitats: the coastal area, the continental shelf, the continental slope and the oceanic area (Fig. 1). The coastal area extends 20-30 km offshore and is characterized by depths from 0 to $20 \mathrm{~m}$. The waters have a high turbidity and low salinity, and the productivity is low due to low levels of available irradiance (Froidefond, 2012; Ternon and Guiral, 2012). The continental shelf is wide and smoothly sloping up to $100 \mathrm{~m}$ depth, about $100 \mathrm{~km}$ offshore. The combination of riverine nutrients input and decreased turbidity creates a productive zone (Smith and Demaster, 1996), which extends more or less seaward, and can reach the slope when conditions are favorable (high river discharge plus retroflection). The continental slope area is characterized by depths from $100 \mathrm{~m}$ to $3,500 \mathrm{~m}$. It is wider with a gentler slope on the west, a region called the Demerara Plateau. The slope area is notched by submarine canyons that favor transport of nutrients to deep waters. In addition, hard substrates have been recently discovered from about $100 \mathrm{~m}$ to $200 \mathrm{~m}$ depth, such as rocky outcrops and a carbonate system, which support a highly diversified and dense macrobenthic community (Moura et al., 2016). The oceanic area reaches depths of more than $4,500 \mathrm{~m}$ and is characterized by blue oligotrophic waters.

\footnotetext{
1. Counihan, R., Aplleby, T., Benford, J., Lis, A., Bevilacqua, V., Lahn, R., Schuler, L., Olio, M., Mcglennon, G., Webb, X. and Martins, M. (2012) Observation de mammifères marins et surveillance acoustique passive - Campagne sismique et géophysique 3D Ouest Guyane Française pour Shell Exploration and Production France SAS, CGGVeritas. 35 pp.

2. Vines, J., Teixeira, M. and Paixão, I. (2010) Marine mammal observer's report during Guyane Maritime 3D/2D seismic survey GFGUMA093DS11C French Guiana for Hardman Petroleum France SAS, 30 pp.
} 
Boat-based visual and acoustic campaigns protocols

Data were collected during three independent boat-based campaigns, conducted on an 18-m long sailing catamaran, aimed at studying seabirds and marine mammals off French Guiana. The GEPOG (Groupe d'Etude et de Protection des Oiseaux de Guyane, a French Guiana NGO) campaign was conducted between July 2011 and June 2012; it consisted of six surveys of four days duration each that were conducted every two months (Fig. 2). Transects were not pre-designed. The campaign covered all the habitats, from the coast to the oceanic area (up to 4,000 m depth), but the effort was concentrated in the center of the EEZ (Fig. 1). A visual effort was performed from sunset to sundown ( 6 am to $6 \mathrm{pm}$ ). At all times, at least two experienced cetacean observers were on duty and rotations were performed every 1 to 4 hours. Mean daily Beaufort Sea state was recorded at the end of the day. When an individual or a group of cetaceans was detected, a sighting was recorded with the following data: species identification to the lowest possible taxonomic level, school size and geographic position. The COHABYS (Consulting company) campaign consisted of five monthly surveys of 5 days each conducted from January to May 2018. The OSL (Ocean Science \& Logistic, a French Guiana NGO) campaign was conducted in 2018 and consisted of four surveys of 10 days each, two done during the rainy season (June and July) and the other two during the dry season (September and October). OSL and COHABYS campaigns focused on the continental slope but an opportunistic effort was carried out on the coastal area and the continental shelf, from the departure harbor to the survey area (Fig. 1). OSL surveys consisted of transects pre-designed to sample the whole slope area, from $100 \mathrm{~m}$ to $3,500 \mathrm{~m}$ depth. COHABYS surveys consisted of transects pre-designed to study the central slope area. OSL and COHABYS followed the same MMO standard protocol (Pelagis Observatory, La Rochelle University, France): the observer crew consisted of three trained observers. At all times, two observers were positioned on the highest part of the vessel roof and each one concentrated his search effort on his forward watch $\left(270^{\circ}\right.$ to $0^{\circ}$ for port observer and $0^{\circ}$ to $90^{\circ}$ for starboard observer) with naked eyes (binoculars were only used to identify sighted individuals). Rotations were organized every hour, so that each observer could rest an hour every two hours. The visual effort was performed from sunset to sundown. Beaufort Sea state, glare severity, and cloud coverage were recorded at each rotation and whenever any of these parameters changed. Sighting data collected included: cetacean species identification to the lowest possible taxonomic level, mother and calf pairs presence (two individuals swimming in close association with an individual $2 / 3$ the size of the larger one or less), school size, behavior, geographic position, observation angle and distance from the boat.

An acoustic effort was also performed, as a complement to the visual effort, in particular to detect cryptic species, such as ziphiids, kogiids and sperm whales. During the GEPOG survey, a SQ03 Sensortech hydrophone (Sensor Technology, Dartmouth, Canada) was used. Acoustic listening stations were randomly performed during the day. Their duration was set to $10 \mathrm{~min}$, in order to record long enough to capture signals, without slowing down the vessel too much. Taxa were identified immediately on site, by ear, by an experienced naturalist, to the lowest possible

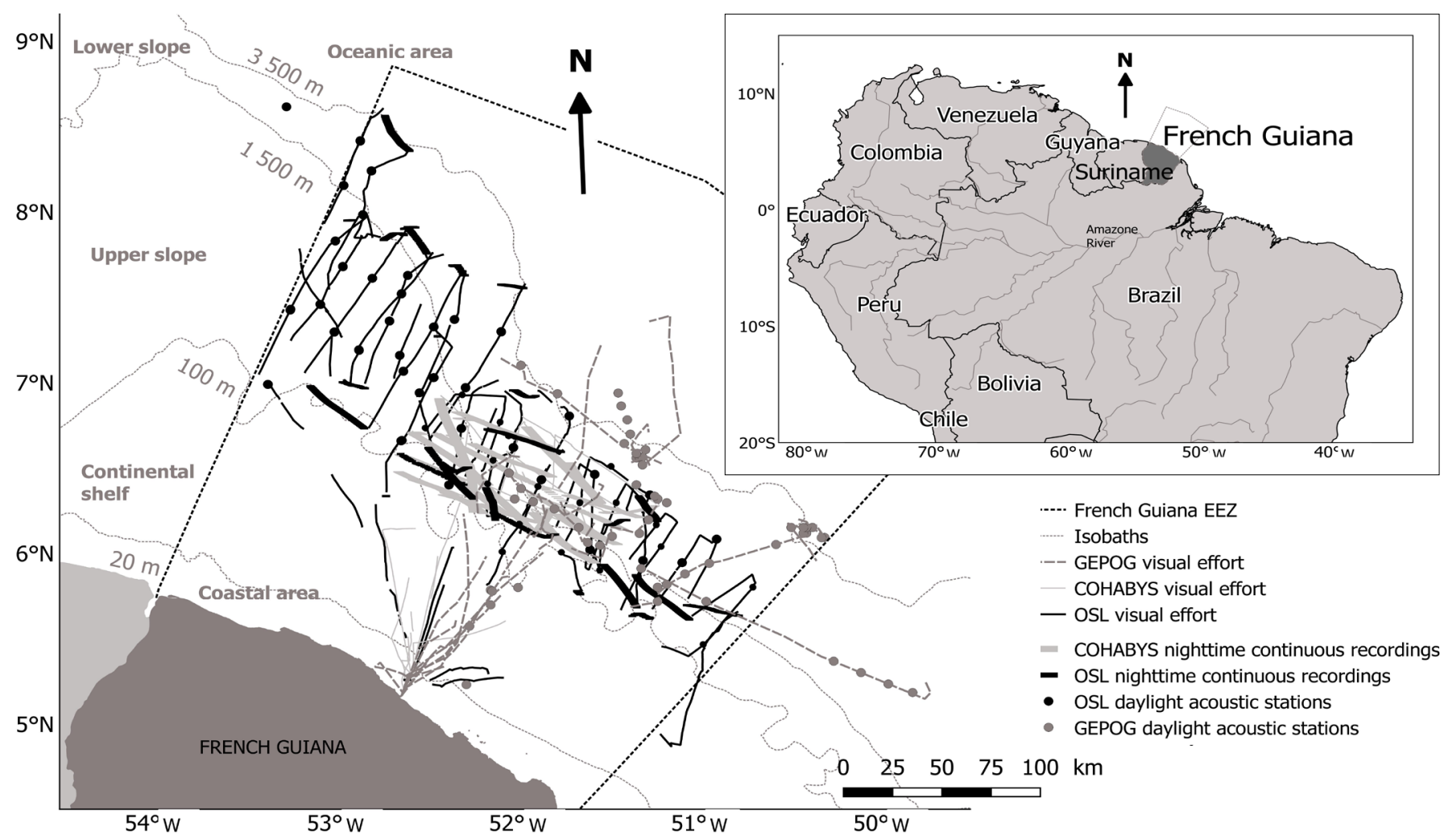

Figure 1. French Guiana EEZ characteristics and spatial distribution of the visual and acoustic effort performed during three boat-based campaigns dedicated to cetaceans, in Beaufort sea state <5: the GEPOG campaign was conducted from July 2011 to June 2012, four days every two months, it consisted in 1,961 km of visual effort and 5510 -min daylight acoustic stations; the COHABYS campaign was performed five days per month from January to May 2018, it consisted in 1,491 km of visual effort and 17 nights of continuous recordings; the OSL campaign consisted in four 10days surveys conducted in June, July, September and October 2018, 3,243 km of visual effort were performed as well as 20 nights of continuous recordings and 64 10-min daylight acoustic stations. 


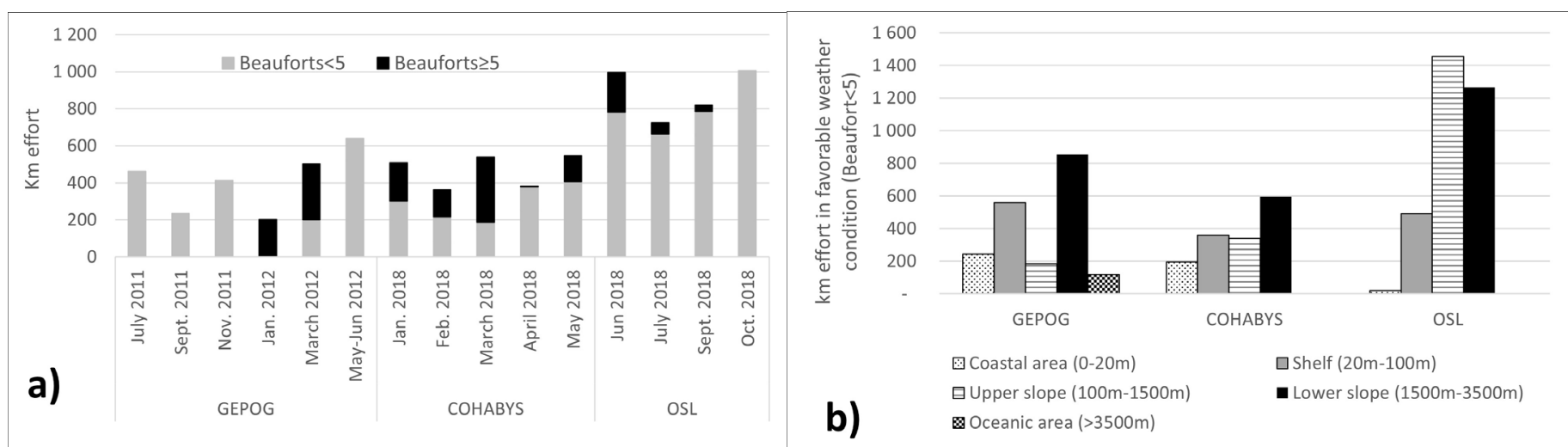

Figure 2. Visual effort performed during the three boat-based campaigns dedicated to cetacean study in French Guiana EEZ: the GEPOG campaign (2011-2012), COHABYS campaign (January to May 2018), and OSL campaign (Jun-July and September-October 2018). The effort of each campaign is detailed by a) survey and b) habitat. On panel b), only effort performed when weather conditions were considered favorable for cetacean visual surveys (Beaufort sea state $<5$ ) is shown.

taxonomic level. During the COHABYS survey, an RS-ORCA acoustic recorder (RS Aqua Ltd., Portsmouth, UK) was deployed at night, whenever Beaufort was $<5$, to collect 5-min acoustic records every five minutes. The vessel was stopped and steered to limit its drift speed. The hydrophone was weighted down to $10 \mathrm{~m}$ depth and secured $25 \mathrm{~m}$ away from the boat with a rope to minimize unwanted noise. During the OSL survey, 10-min daylight acoustic recordings were performed every two hours, whenever the weather was favorable (Beaufort < 5), using a H2a-XLR hydrophone (Aquarian Audio \& Scientific, Anacortes, WA, USA). This was also deployed during favorable weather conditions at night, when the boat was not shipping, and acoustic data were continuously recorded all night round. The hydrophone was connected to a recorder (ZOOM 1), and recorded as $96 \mathrm{kHz}, 24$ bit .wav files. The hydrophone was weighted down to $10 \mathrm{~m}$ depth to avoided unwanted noise.

\section{Data analyses}

Only visual and acoustic data collected with favorable sea conditions (Beaufort < 5) were considered for the analysis. In order to analyze the cetacean community composition, we summed the number of sightings for each taxon and each campaign (GEPOG, OSL, COHABYS). We then calculated the sighting frequency for groups and individuals, as $n_{\mathrm{si}} / \mathrm{N}_{\mathrm{s}}$, where $\mathrm{n}_{\mathrm{si}}$ was the number of groups/individuals sighted for species $i$ and $\mathrm{N}_{\mathrm{s}}$ the total number of cetacean groups/individuals sighted. Since the protocols were not totally identical between GEPOG, COHABYS and OSL campaigns, these numbers were computed separately for each campaign. Then, species habitat-specific encounter rates were calculated for the most frequently observed species, as the number of groups sighted per $100 \mathrm{~km}$ effort in the considered habitat and for the considered campaign. Again, data were processed independently for each campaign. Because of the small sample sizes, we could not compute species habitatspecific encounter rates for each survey to obtain campaign mean encounter rates; instead, for each campaign, we summed data over all surveys to compute a global habitat-specific encounter rate. Habitats were defined as: coastal area (0-20 m depth), shelf (20-100 m depth), upper slope (100-1,500 m depth), lower slope (1,500-3,500 m depth) and oceanic area (>3,500 m depth). When the effort was less than $150 \mathrm{~km}$ for a campaign in a particular habitat, the encounter rates were not calculated.

Regarding acoustic data, during the GEPOG survey, taxa were identified immediately on site, during each acoustic daylight listening station. Regarding COHABYS and OSL data, sound recordings were processed in a continuous batch of audio files to create a full-bandwidth, Long-Term Spectral Average (LTSA) in PAMGuard software (Gillespie et al., 2009) with an averaging interval of $5 \mathrm{sec}$. Whistle and moan detector (WMD) was used to search for frequency-modulated tonal sounds (such as dolphin whistles and whale calls) within a frequency band of $50 \mathrm{~Hz}$ to $48 \mathrm{kHz}$. Once the data had been processed by PAMGuard, they were studied manually, using Raven Pro 1.5 software (http://www.birds.cornell.edu/raven, accessed 2 June 2021), to verify tonal sounds detected by the WMD and to search for frequency-modulated whistles, pulsed calls, and echolocation clicks. Two spectrograms were used, with frequency ranges of 0-25 kHz and 25-50 kHz. Selected sounds were played back over headphones (at normal or modified speed). Cetacean species-group vocalizations were searched for in the following frequency bands: baleen whale tonal calls, 0-2000 Hz, sperm whale click trains and codas, $0-24 \mathrm{kHz}$, beaked whale click trains, $20-48 \mathrm{kHz}$, delphinid tonal calls, click trains, burst pulse calls, 0-48 kHz. All cetacean sounds were selected and recorded as a detection. For each detection, start and end times were recorded in UTC, along with the type of sound (whale moan, whistles, pulsed calls, and clicks), lowest possible taxonomic level and geographic position. Afterward, for each taxon and each campaign, we determined the number (na) of daylight listening stations and the number of nights of continuous recording, with at least one acoustic detection of the taxon. The frequency then was computed the following way: na/ $\mathrm{Na}$ with $\mathrm{Na}$ the total number of daylight listening stations or nights of continuous recording. Since the protocols varied between GEPOG, COHABYS and OSL campaigns, these numbers were computed separately for each campaign.

Finally, the monthly presence of cetaceans in French Guiana was described. For this qualitative analysis, all visual and acoustic records from all campaigns were combined, including those detections done under non-favorable weather conditions (i.e. Beaufort sea state $>4$ ). 


\section{Results}

Visual and acoustic efforts

Regarding visual effort, a total of $6,686 \mathrm{~km}$ were surveyed under favorable weather conditions (Beaufort $<5$ ), during GEPOG, COHABYS and OSL campaigns. During the GEPOG campaign, $1,961 \mathrm{~km}$ of effort were done in favorable weather conditions (Fig. 2a). Most of the effort was conducted on the shelf ( $559 \mathrm{~km}$; Fig. $2 \mathrm{~b}$ ) and on the lower slope (855 km). The COHABYS campaign resulted in 1,491 $\mathrm{km}$ of effort performed in favorable weather conditions (Fig. 2a). Most of the effort was conducted on the shelf $(360 \mathrm{~km})$, on the upper slope $(340 \mathrm{~km})$, and on the lower slope (596 km). The OSL study totaled $3,243 \mathrm{~km}$ of effort in favorable weather conditions. Most of the effort was conducted on the upper slope $(1,456 \mathrm{~km})$ and on the lower slope (1,266 km). Overall, bad weather conditions (Fig. 2a). Because of the designs of the surveys, no effort was performed in August and December and the effort conducted in the oceanic area was limited.

A total of 132 groups of cetaceans were sighted in favorable weather conditions, including 52 groups and 1,315 individuals for the GEPOG, 16 groups and 151 individuals for COHABYS and 64 groups and 1,475 individuals for OSL (Table 1). Mean encounter rates per $100 \mathrm{~km}$ effort per campaign, over all surveys, were $3.0 \pm 2.6,1.0 \pm 0.7$, and $2.0 \pm 0.4$ groups $/ 100 \mathrm{~km}$ for the GEPOG, COHABYS and OSL campaigns, respectively.

As for acoustic effort, $119 \mathrm{~h}$ and $10 \mathrm{~min}$ daylight listening stations were performed ( 55 during GEPOG campaigns and 64 during OSL campaigns; Fig. 1). In addition, underwater sound was recorded continuously for 37 nights (20 during OSL campaigns and 17 during COHABYS campaigns), which totalized 359 hours of night acoustic recordings. Cetaceans were acoustically detected at least once during $51 \%$ and $28 \%$ of the of the GEPOG and OSL daylight listening stations, respectively. As for night continuous recordings, at least one cetacean detection was made during $100 \%$ and $85 \%$ of the nights for COHABYS and OSL respectively (Table 2).

\section{Species richness and dominant taxa}

In total, 13 cetacean species were visually identified in favorable weather conditions (Table 1): one kogiid, the dwarf sperm whale (Kogia sima), one balaenopterid, the humpback whale, as well as 11 species of delphinids. One unidentified Balaenoptera was also sighted, and two species were sighted in bad weather conditions: the pygmy killer whale (Feresa attenuata) and the sperm whale (Table 1). Finally, two taxa were identified only from acoustic data: the sei whale (Balaenoptera borealis) and unidentified ziphiids (Table 2). The number of identified taxa increased rapidly to nine species during the first half of the GEPOG campaign (Fig. 3), it then remained constant with no new taxa identified during COHABYS campaign, and it finally increased rapidly again to 14 identified taxa during OSL dry season surveys.

Delphinidae was the cetacean family most frequently sighted.

Table 1. List of cetacean taxa visually identified in favorable weather condition (Beaufort < 5), during three boat-based campaigns dedicated to cetacean study in French Guiana EEZ: the GEPOG campaign (2011-2012), COHABYS campaign (January to May 2018), and OSL campaign (Jun-July and September-October 2018). For each taxon, the number and frequency of sightings is given for groups and individuals. * indicates a species observed only in bad weather conditions (Beaufort $>4$ ).

\begin{tabular}{|c|c|c|c|c|c|c|}
\hline \multirow{2}{*}{ Name of taxon } & \multicolumn{3}{|c|}{ Number of groups (individuals) sightings } & \multicolumn{3}{|c|}{ Sighting frequency in \% for groups (individuals) } \\
\hline & GEPOG & COHABYS & OSL & GEPOG & COHABYS & OSL \\
\hline \multicolumn{7}{|l|}{ Physeteridae } \\
\hline Sperm whale (Physeter macrocephalus) & * & & & * & & \\
\hline Kogiidae & & & $2(2)$ & & & $3(<1)$ \\
\hline Dwarf sperm whale (Kogia sima) & & & $2(2)$ & & & $3(<1)$ \\
\hline Baleinopteridae & & & $4(7)$ & & & $6(<1)$ \\
\hline Humpback whale (Megaptera novaeangliae) & & & $2(5)$ & & & $3(<1)$ \\
\hline Balaenoptera sp. & & & $1(1)$ & & & $2(<1)$ \\
\hline Unidentified balaenopterid & & & $1(1)$ & & & $2(<1)$ \\
\hline Delphinidae & $52(1.315)$ & $16(151)$ & $58(1.466)$ & $100(100)$ & $100(100)$ & $91(99)$ \\
\hline Bottlenose dolphin (Tursiops truncatus) & $5(20)$ & $3(13)$ & $15(147)$ & $10(2)$ & $19(9)$ & $23(10)$ \\
\hline Risso's dolphin (Grampus griseus) & & & $1(2)$ & & & $2(<1)$ \\
\hline Fraser's dolphin (Lagenodelphis hosei) & & & $2(80)$ & & & $3(5)$ \\
\hline Pilot whale (Globicephala macrorhynchus) & $1(25)$ & $1(15)$ & $1(10)$ & $2(2)$ & $6(10)$ & $2(<1)$ \\
\hline Melon-headed whale (Peponocephala electra) & $3(400)$ & $1(4)$ & $4(350)$ & $6(30)$ & $6(3)$ & $6(24)$ \\
\hline Pygmy killer whale (Feresa attenuata) & & * & & & * & \\
\hline Spinner dolphin (Stenella longirostris) & $4(178)$ & & $3(255)$ & $8(13)$ & & $5(17)$ \\
\hline Atlantic spotted dolphin (Stenella frontalis) & $7(208)$ & $3(14)$ & $3(95)$ & $14(16)$ & $19(9)$ & $5(6)$ \\
\hline Pantropical spotted dolphin (Stenella attenuata) & $7(385)$ & $3(90)$ & $16(442)$ & $13(29)$ & $19(60)$ & $25(30)$ \\
\hline Long-beaked common dolphin (Delphinus delphis) & $5(27)$ & $1(7)$ & $1(15)$ & $10(2)$ & $6(5)$ & $2(1)$ \\
\hline Guiana dolphin (Sotalia guianensis) & $10(35)$ & $1(5)$ & & $19(3)$ & $6(3)$ & \\
\hline Rough-toothed dolphin (Steno bredanensis) & 1(9) & & & $2(<1)$ & & \\
\hline Unidentified delphinid & $9(28)$ & $3(3)$ & $12(70)$ & $17(2)$ & $19(2)$ & $19(5)$ \\
\hline TOTAL & $52(1.315)$ & $16(151)$ & $64(1.475)$ & $100(100)$ & $100(100)$ & $100(100)$ \\
\hline
\end{tabular}


Table 2. List of cetacean taxa identified acoustically, in favorable weather condition (Beaufort $<5$ ), during three boat-based campaigns dedicated to cetacean study in French Guiana EEZ: the GEPOG campaign (2011-2012), COHABYS campaign (January to May 2018), and OSL campaign (Jun-July and September-October 2018). For each taxon, number and frequency of 10 min daylight acoustic stations and nights of continuous recordings with at least one detection are given.

\begin{tabular}{|c|c|c|c|c|}
\hline \multirow[t]{2}{*}{ Name of taxon } & \multicolumn{2}{|c|}{$\begin{array}{l}\text { Number (frequency in \%) of daylight acoustic } \\
\text { stations with at least one acoustic record of the } \\
\text { considered taxon }\end{array}$} & \multicolumn{2}{|c|}{$\begin{array}{l}\text { Number (frequency in \%) of continuous night } \\
\text { recordings with at least one acoustic record of the } \\
\text { considered taxon }\end{array}$} \\
\hline & GEPOG (57 stations) & OSL (64 stations) & COHABYS (17 nights) & OSL (20 nights) \\
\hline Physeteridae & $10(18 \%)$ & & & $2(10 \%)$ \\
\hline Sperm whale (Physeter macrocephalus) & $10(18 \%)$ & & & $2(10 \%)$ \\
\hline Baleinopteridae & & $2(4 \%)$ & $1(6 \%)$ & $4(20 \%)$ \\
\hline Humpback whale (Megaptera novaeangliae) & & & $1(6 \%)$ & $3(15 \%)$ \\
\hline Sei whale (Balaenoptera borealis) & & $1(2 \%)$ & & \\
\hline Unidentified balaenopterid & & $1(2 \%)$ & & $1(5 \%)$ \\
\hline Ziphiidae & & & $2(12 \%)$ & \\
\hline Unidentified ziphiid. & & & $2(12 \%)$ & \\
\hline Delphinidae & $20(36 \%)$ & $17(27 \%)$ & $15(88 \%)$ & $16(80 \%)$ \\
\hline Bottlenose dolphin (Tursiops truncatus) & $1(2 \%)$ & $1(2 \%)$ & & $1(5 \%)$ \\
\hline Pilot whale (Globicephala macrorhynchus) & & $1(2 \%)$ & & $2(10 \%)$ \\
\hline Melon-headed whale (Peponocephala electra) & $2(4 \%)$ & & & \\
\hline Spinner dolphin (Stenella longirostris) & $1(2 \%)$ & & & $3(15 \%)$ \\
\hline Pantropical spotted dolphin (Stenella attenuata) & $3(5 \%)$ & $3(5 \%)$ & & $2(10 \%)$ \\
\hline Long-beaked common dolphin (Delphinus delphis) & $1(2 \%)$ & & & \\
\hline Guiana dolphin (Sotalia guianensis) & & $1(2 \%)$ & & \\
\hline Unidentified delphinid & $12(22 \%)$ & $10(16 \%)$ & 15 (88\%) & $8(40 \%)$ \\
\hline All cetacean species & $28(51 \%)$ & $18(28 \%)$ & $17(100 \%)$ & $17(85 \%)$ \\
\hline
\end{tabular}

It comprised $91 \%$ to $100 \%$ of sighted groups and $99 \%$ to $100 \%$ of recorded individuals, depending on the campaign (Table 1). Pantropical spotted dolphin (Stenella attenuata) was the most frequent species both in terms of group sightings (it accounted for $13 \%$ to $25 \%$ of the groups depending on the campaign) and the number of recorded individuals ( $29 \%$ to $60 \%$ of the counted individuals, depending on the campaign, Table 1). Four other delphinid species dominated the group sightings: the bottlenose dolphin (up to $23 \%$ of the groups), the Guiana dolphin (up to $19 \%$ of the groups), the Atlantic spotted dolphin (Stenella frontalis, up to $19 \%$ of the groups), as well as the long-beaked common dolphin (Delphinus delphis, up to $10 \%$ of the groups). Finally, two species dominated the number of recorded individuals: the melon-headed whale (Peponocephala electra, up to $30 \%$ of the total individuals) and the spinner dolphin (up to $17 \%$ of the total individuals, Table 1). Species associations were observed four times. They involved melon-headed whale and either pantropical spotted dolphin $(n=3)$ or Atlantic spotted dolphin $(n=1)$.

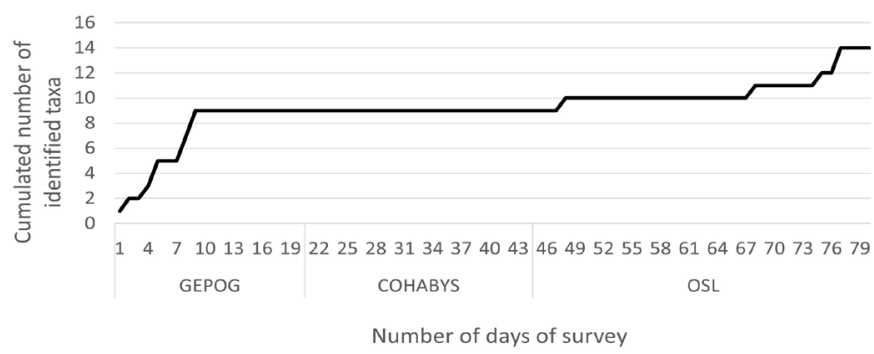

Figure 3. Cumulated number of taxa visually identified in favorable weather condition (Beaufort < 5), during three boat-based survey campaigns dedicated to cetacean study in French Guiana EEZ: the GEPOG campaign (2011-2012), COHABYS campaign (January to May 2018), and OSL campaign (Jun-July and September-October 2018).

\section{Species distribution and phenology}

Regarding the delphinids, all but one of the 11 Guiana dolphin sightings were collected in the coastal area (Fig.4). The longbeaked common dolphins were all found on the shelf $(n=$ 7; Fig. 4). The bottlenose and the Atlantic spotted dolphins were observed on both the shelf and the upper slope (23 and 13 sightings respectively; Fig. 4). However, the bottlenose showed higher encounter rates on the shelf with 0.6 to 0.9 group $/ 100 \mathrm{~km}$ effort, depending on the campaign, against 0.3 to 0.7 group $/ 100 \mathrm{~km}$ on the upper slope (Fig. $5)$. All the melon-headed whales $(n=9)$ and the spinner dolphins $(n=7)$ were observed on the slope (Figure 4$)$. Both species seemed to favor the upper slope: the melon-headed whale had encounter rates from 0.3 to 1.6 group $/ 100 \mathrm{~km}$ effort on the upper slope, against 0 to 0.2 group $/ 100 \mathrm{~km}$ effort on the lower slope (Fig. 5). The spinner dolphin showed sighting rates from 0 to 2.2 groups $/ 100 \mathrm{~km}$ effort on the upper slope against 0 to 0.2 group $/ 100 \mathrm{~km}$ effort on the lower slope (Fig. 5). Apart from one group sighting, the pantropical spotted dolphin was always recorded on the slope ( $n=26$; Fig. 4). All these most frequently sighted species seemed to be present year-round (Table 3 ). In addition, mother and calf pairs were recorded for all of them, except the long-beaked common dolphin and the Guiana dolphin. Less frequent species, the Risso's dolphin (Grampus griseus), the Fraser's dolphin (Lagenodelphis hosei), the pilot whale (Globicephala macrorhynchus), and the pygmy killer whale were found on the slope, except for the rough-toothed dolphin (Steno bredanensis) that was observed on the shelf (Fig. 4).

Regarding balaenopterids, the two humpback whale sightings were a mother and calf pair and then a group of three that included a mother and calf pair. Both groups were observed close to 


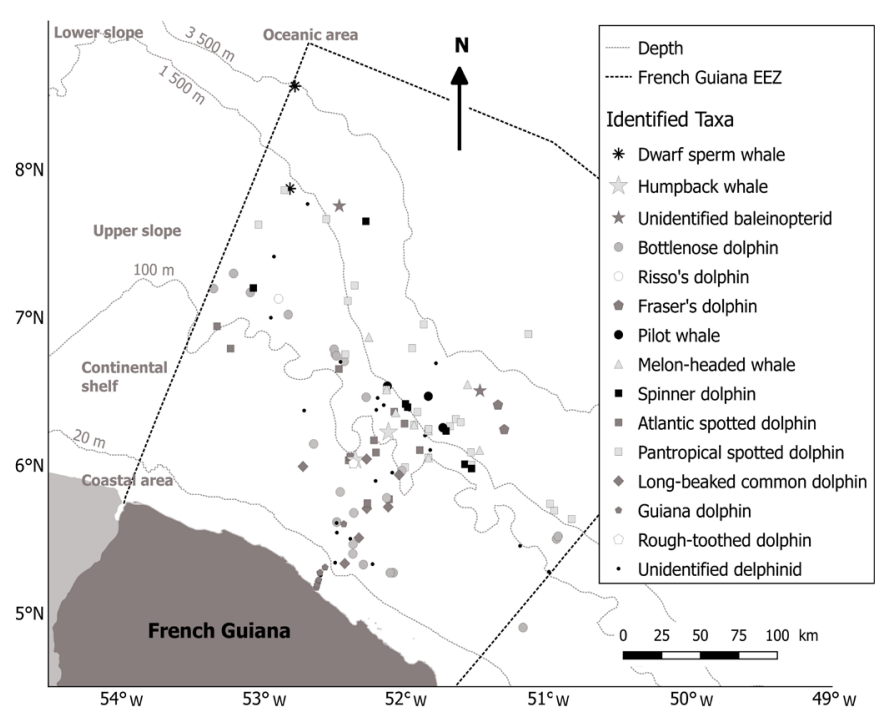

Figure 4. Cetacean visual sightings collected in favorable weather condition (Beaufort $<5$ ), during three boat-based campaigns dedicated to cetacean study in French Guiana EEZ: the GEPOG campaign (20112012), COHABYS campaign (January to May 2018), and OSL campaign (Jun-July and September-October 2018).

the $100 \mathrm{~m}$ depth isobaths, during OSL September and October surveys (Fig. 4; Table 3). The species was also acoustically recorded on the slope, once close to the $100 \mathrm{~m}$ depth isobath in January, and three times in June, in waters from $900 \mathrm{~m}$ to $2,600 \mathrm{~m}$ depth. The unidentified balaenopterids were sighted twice in October on the lower slope (Fig. 4; Table 3) and were acoustically recorded alongside the $1,500 \mathrm{~m}$ isobath, once in June and once in October (Fig. 6). The sei whale acoustic record was on the shelf in October (Fig. 6).

As for the other families, the two observations of dwarf sperm whales were recorded on the shelf at $1,500 \mathrm{~m}$ and $3,500 \mathrm{~m}$ depth (Fig. 4). Sperm whale and ziphiids acoustic detections were made on the lower slope (Fig. 6). A group of sperm whales with calves was sighted in June and another one in November, in Beaufort $>4$, and the species was also found in October acoustic records (Table 3 ).

\section{Discussion}

\section{Study contribution and limits}

This study provided new information on the cetacean species occurring year-round in the entire French Guiana EEZ by combining visual and acoustic data obtained from three boat-based campaigns. Overall, a total of $6,686 \mathrm{~km}$ were visually surveyed under favorable weather conditions (Beaufort < 5 ) and 132 groups of cetaceans were sighted. Five cetacean families and 15 species were identified with certainty. The delphinid was, by far, the cetacean family most frequently sighted (91\% to $100 \%$ of groups and $99 \%$ to $100 \%$ of individuals per campaign). The most frequent species in the area were identified, along with their distribution and phenology: the Guiana dolphin was found in the coastal area (0-20 m), the long-beaked common dolphin was sighted on the shelf (20-100 m), along with the bottlenose dolphin and the Atlantic spotted dolphin that were also common on the upper slope (100-1,500 m). Finally, the spinner dolphin, the melon-headed whale and the pantropical spotted dolphin were observed on the slope (100-3,500 m). The results suggest these species may be found in French Guiana waters all year round and mother and calf pairs, an indicator of reproduction, were observed for all of them except the long-beaked common dolphin and the Guiana dolphin. Mother and calf pairs of humpback whales were sighted twice as well as groups of sperm whales with calves.

The main limitations of our study were due to the small sample sizes per habitat and per season and to the heterogeneity of

Table 3. Monthly presence of cetacean species detected visually and/or acoustically under all-weather conditions, during three boat-based campaigns dedicated to cetacean study in French Guiana EEZ: the GEPOG campaign (2011-2012), COHABYS campaign (January to May 2018), and OSL campaign (Jun-July and September-October 2018). No effort was performed in August and December. "O" = Sighted at least once; "MC" $=$ mother and calf pair sighted at least once, "Ac" = acoustic detection only.

\begin{tabular}{|c|c|c|c|c|c|c|c|c|c|c|c|c|}
\hline Name of taxon & Jan & Feb & Mar & Apr & May & Jun & Jul & Aug & Sep & Oct & Nov & Dec \\
\hline Sperm whale & & & & & & MC & & & & Ac & $\mathrm{MC}$ & \\
\hline Dwarf sperm whale & & & & & & & & & & 0 & & \\
\hline Unidentified ziphiids & & & Ac & & & & & & & & & \\
\hline Humpback whale & $\mathrm{Ac}$ & & & & & Ac & & & MC & MC & & \\
\hline Sei whale & & & & & & & & & & Ac & & \\
\hline Unidentified balaenopterid & & & & & & Ac & & & & 0 & & \\
\hline Bottlenose dolphin & & 0 & 0 & 0 & 0 & $\mathrm{MC}$ & 0 & & $\mathrm{MC}$ & 0 & 0 & \\
\hline Risso's dolphin & & & & & & & & & & 0 & & \\
\hline Fraser's dolphin & & & & & & 0 & & țo & & & & 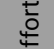 \\
\hline Pilot whale & & & & 0 & & Ac & & $\begin{array}{l}\infty \\
0 \\
2\end{array}$ & MC & & & 욱 \\
\hline Melon-headed whale & & & 0 & & 0 & MC & 0 & & 0 & & MC & \\
\hline Pygmy killer whale & & & 0 & & & & & & & & & \\
\hline Spinner dolphin & MC & & & & & MC & Ac & & 0 & 0 & MC & \\
\hline Atlantic spotted dolphin & & & 0 & & 0 & MC & 0 & & MC & & 0 & \\
\hline Pantropical spotted dolphin & 0 & & & 0 & & 0 & MC & & MC & MC & & \\
\hline Long-beaked common dolphin & 0 & 0 & & 0 & 0 & 0 & 0 & & 0 & & 0 & \\
\hline Guiana dolphin & 0 & & & & 0 & Ac & 0 & & 0 & & 0 & \\
\hline Rough-toothed dolphin & & & & & & & 0 & & & & & \\
\hline
\end{tabular}




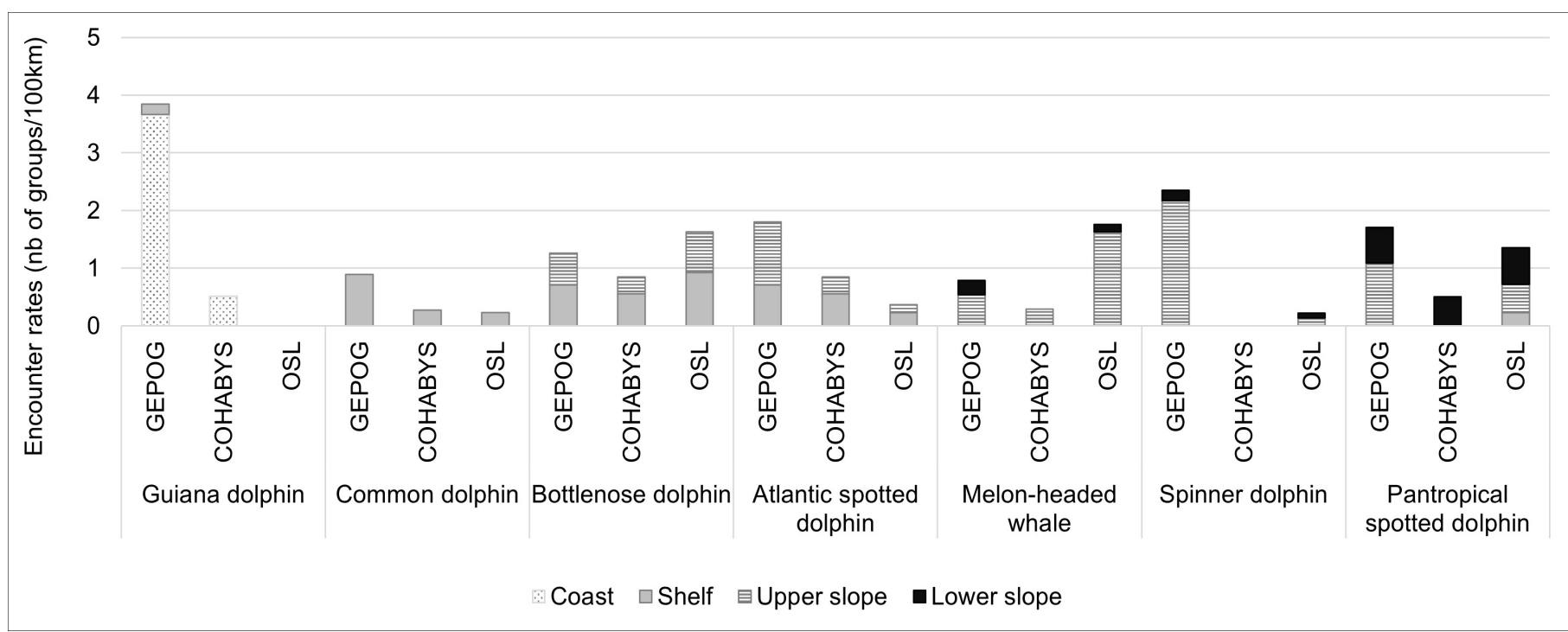

Figure 5. Encounter rates of most frequently sighted cetacean species in favorable weather condition (Beaufort $<5$ ), during three boat-based campaigns dedicated to cetacean study in French Guiana EEZ: the GEPOG campaign (2011-2012), COHABYS campaign (January to May 2018), and OSL campaign (Jun-July and September-October 2018). Encounter rates were computed as the number of groups sighted per $100 \mathrm{~km}$ of effort, in each habitat. As the effort was less than $150 \mathrm{~km}$ for the oceanic habitat for all campaigns, as well as in the coastal habitat for OSL campaign, the encounter rates were not computed in these cases.

effort between seasons and between habitats. Small sample sizes were mainly due to the use of a small vessel that reduced the observation distance, the limited overall effort, and to the fact that we could not aggregate the data over the three campaigns as the GEPOG survey protocol was not standard. Heterogeneity of effort was due to the design of the campaigns: there was a reduced effort in January and February, none in August and December as well as a limited effort in coastal and oceanic areas. In addition, the seasonal variability of effort was different in each habitat and vice-versa. Consequently, robust quantitative analyses, such as comparisons of the community species richness and composition between seasons and between habitats, could not be computed. In addition, we may have missed or underestimated the presence of some species, in particular balaenopterids that may cross the offshore EEZ during specific seasons, or cryptic oceanic species, such as ziphiids.

\section{Species richness}

In total, five cetacean families and 15 species were identified with certainty during the GEPOG, COHABYS and OSL surveys including: one kogiid, the dwarf sperm whale, the sperm whale, some unidentified ziphiids, one balaenopterid, the humpback whale, as well as 12 species of delphinids. The sei whale was detected acoustically but the identification will be considered certain only when a visual detection is made. As the cumulated number of taxa identified did not reach a plateau, it seems that all the species that may be found in the area have not been identified yet. The IUCN France et al. (2017) published the red list of threatened species in French Guiana, based on a compilation of data collected before 2017, including the GEPOG campaign. Seventeen species of cetaceans are listed in this work. Among these species, five were not recorded during our three campaigns: the fin whale, the blue whale (Balaenoptera musculus), the Cuvier's beaked whale, the killer whale (Orcinus orca), and the false killer whale (Pseudorca

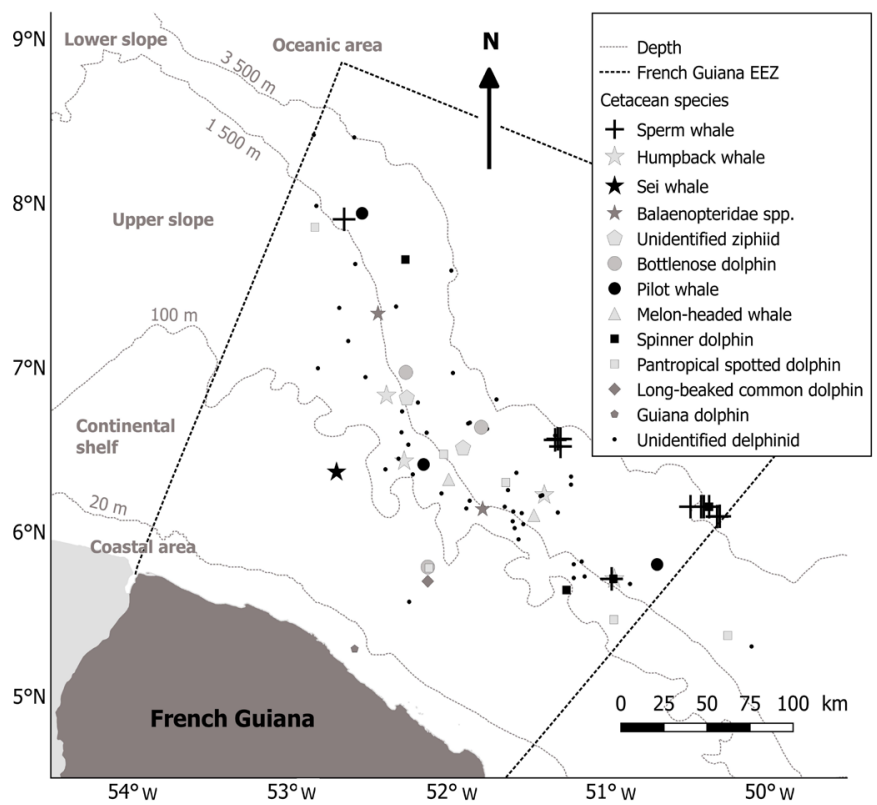

Figure 6. Acoustic detections of cetaceans collected during the $10 \mathrm{~min}$ daylight acoustic stations and the nighttime continuous recordings performed in favorable weather condition (Beaufort $<5$ ), during three boat-based campaigns dedicated to cetacean study in French Guiana EEZ: the GEPOG campaign (2011-2012), COHABYS campaign (January to May 2018), and OSL campaign (Jun-July and September-October 2018).

crassidens). Conversely, three species were identified for the first time with certainty during COHABYS and OSL campaigns and are not listed in the IUCN France et al. (2017) report: the dwarf sperm whale, the Fraser's dolphin and the pygmy killer whale. In addition, two new species were recently identified during the GreenPeace Pole to Pole campaign conducted in September $2019^{3}$ and during the last oil exploration survey performed offshore French Guiana in January 2020 (L. Martinez, unpub. data):

3. Van Canneyt, O., Dorémus, G., Ifticene, E., Bordin, A., Rinaldi, R., Vanhoucke, M., and Laran, S. (2019) La mégafaune marine au large de la Guyane française - Compte rendu de campagne à bord de I'Esperanza. Observatoire Pelagis (UMS 3462, Université de La Rochelle / CNRS), Greenpeace, GEPOG, Evasion Tropicale: 16 pp. 
the Clymene dolphin (Stenella clymene) and the Bryde's whale (Balaenoptera brydei/edeni). Hence, in total, five families and 22 species of cetaceans have been identified so far with certainty in French Guiana EEZ.

In neighboring regions, cetacean dedicated studies have not been conducted so far. However, compilations of data collected during oil exploration surveys and strandings have been performed. In the Northern states of Brazil (Amapá, Pará and Maranhão), 17 species have been identified (Siciliano et al., 2008; Ristau, 2012; Silva et al., 2013). Among them, only one has never been sighted in French Guiana: the minke whale (Balaenoptera acutorostrata). In Suriname, 16 species have been identified so far (de Boer, 2015; de Boer and Willems, 2015). Two of them have never been identified with certainty in French Guiana: the Antarctic minke whale (Balaenoptera bonaerensis) and the sei whale. Hence, apart from three balaenopterids, all species identified so far in neighboring regions have been identified in French Guiana. This suggests that the odontocetes that regularly frequent French Guiana waters have all been identified but that all the balaenopterids that pass through the region far offshore during their migration have not yet been recorded.

The high cetacean species richness observed off French Guiana complies with the global marine mammal diversity studies conducted by Albouy et al. (2017), Kaschner et al. (2011) and Pompa et al. (2011). These works revealed a higher concentration of cetacean species between $30-40^{\circ}$ North and South, in particular in coastal areas, associated with high primary productivity. Up to 28 species of odontocetes and eight species of mysticetes were found in these regions, with an average of 24 marine mammal species (Kaschner et al., 2011; Pompa et al., 2011). In Albouy et al.'s (2017) study, French Guiana even appears in the $2.5 \%$ spots with the greatest marine mammal species richness.

\section{Dominant taxa}

Like in our study, in most previous campaigns ${ }^{1,2}$ (Mannocci et al., 2013), delphinids strongly dominated the cetacean community, accounting for $87 \%, 90 \%$ and $88 \%$ of the sightings, respectively, and $99 \%$ of individuals in all studies. On a worldwide scale, Kaschner et al. (2011) and Pompa et al. (2011) also found that delphinid species richness was concentrated near tropical and subtropical coasts. During Martinez et al.'s (2019) campaign, the delphinid was still the most frequently sighted cetacean family, but it represented only $44 \%$ of sightings and $67 \%$ of individuals. This difference was due to a high proportion of unidentified cetacean observations ( $26 \%$ of sightings and $28 \%$ of individuals) and a high number of humpback whale sightings $(26 \%$ of the total group and $5 \%$ of individuals). This survey was conducted in October-November on the continental slope, which is precisely the period and habitat when and where the species was sighted during our campaigns. We may then hypothesize that these are preferred period and habitat for the species in the area, which would explain the high frequency of sightings collected during Martinez et al.'s (2019) study.

Regarding dominant species, during Mannocci et al.'s (2013) campaign, the bottlenose dolphin was the most frequently sighted species in all habitats (50\% of the sightings), except the coastal area, where the second most abundant species, the Guiana dolphin was mainly sighted. During both seismic oil exploration campaigns conducted on the continental slope area1, 2, the species most often recorded was the spinner dolphin (31\% and $33 \%$ of the sightings, respectively). During Martinez et al.'s (2019) campaign, apart from the humpback whale, the most frequently sighted species were: the Atlantic spotted dolphins, the bottlenose dolphins, and the long-beaked common dolphins on the upper slope $(13 \%, 10 \%, 5 \%$ of the sightings, respectively), and pantropical spotted dolphins over the lower slope (15\% of sightings). In the offshore waters of Suriname, de Boer (2015) collected cetacean sightings during a geophysical seismic survey (May-September 2012) on the lower slope area $(1,200-3,600 \mathrm{~m})$. The species most frequently sighted were the sperm whale, the spinner dolphin, the melon-headed whale, and the pantropical spotted dolphin (12\%, $14 \%, 5 \%$ and $5 \%$ of the sightings). These results confirm that, as suggested by our study, the bottlenose dolphin, the melon-headed whale, the spinner dolphin, the Atlantic spotted dolphin, the pantropical spotted dolphin and the long-beaked common dolphin are the delphinid species most frequently sighted offshore in the region. These findings also support that, on the continental slope area, the spinner dolphin, the pantropical spotted dolphin and the melon-headed whale have a more offshore distribution than the bottlenose, the Atlantic spotted and the long-beaked common dolphins. Differences observed between studies in the sighting frequencies of the dominant species can be explained by different geographic and seasonal variability of effort, between-years environmental variabilities, as well as the variety of platforms used (planes or large oceanographic vessels or small sailing boat). The only other study, apart from ours, that surveyed the coastal area (Mannocci et al. 2013) confirmed the Guiana dolphin as the dominant species in this habitat. This finding is consistent with available knowledge on this species known to occur only in coastal waters (da Silva et al., 2010). Recent studies have confirmed the species is present all year round in French Guiana coastal waters, as suggested by our results, and they also showed that the species breeds in the area ( $A$. Bordin, unpub. data).

During de Boer's (2015) campaign, a high proportion of sperm whale sightings was recorded ( $12 \%$ of sighted groups and $3 \%$ of individuals). During our study, only two groups of sperm whales were sighted in bad weather conditions and during previous campaigns sperm whales made from $2 \%$ to $4 \% 1,2$ (Mannocci et al., 2013; Martinez et al., 2019) of the sightings. In Suriname, de Boer (2015) highlighted that sperm whales were most frequently seen in the vicinity of the Demerara Plateau. The Demerara Plateau extends over the whole Suriname continental shelf, but it is only found on the western part of French Guiana EEZ and we conducted only a limited effort on this habitat. This could explain the lower frequency of sperm whale sightings found in our study compared to de Boer's (2015) campaign. Interestingly, de Boer (2015) recorded several sperm whale subadult and three calf sightings and concluded that the species uses the area for breeding/nursing. This is consistent with the two observations of groups with calves collected during our study.

\section{Humpback whale}

Our study contributes with new records of humpback whales in the region, including both acoustic recordings (one in January and three in June) and observations of mother-calf pairs (one in September and one in October). The humpback whale "A" stock, located in the western South Atlantic, has its main reproductive site at Abrolhos Bank on the Eastern Brazilian coast. The main period of occurrence in the Abrolhos Bank is from July to 
November, but earlier and later observations have been recorded (Ristau et al., 2020). The number of humpback whales wintering off Brazil increased by nearly 27\% between 2008 and 2012 (Bortolotto et al., 2016). In Pará and Maranhão states, between 2002 and 2011, Ristau et al. (2020) recorded four humpback whale strandings as well as a sighting and concluded to a possible extension of the species range or the recolonization of a historical breeding area along the Brazilian coast. Considering that most records of humpback whales (including ours) in French Guiana EEZ comprise mother-calf pairs and that they occur between June-November (except for one acoustic detection in January) like in Abrolhos Bank, we hypothesize that they belong to the " $A$ " stock that is currently extending its range.

\section{Conclusion}

This study provided new information on the cetacean species occurring year-round in the entire French Guiana EEZ by combining data obtained from three boat-based campaigns. With five families and 22 species of cetaceans identified so far with certainty, French Guiana is a region characterized by a high species richness. The most frequent species in the area were identified, along with their distribution and phenology. The community is dominated by seven species of delphinids, including the Guiana dolphin which is only found along the east coast of Central and South America (from Honduras to Rio de Janeiro). Mother and calf pairs, an indicator of reproduction, were observed for five of these species. The region seems to also host some sperm whale nursery pods and to be a nursery for humpback whales that potentially belong to the "A" stock. Recently, the Guiana dolphin was classified as Endangered and the sperm whale as Vulnerable in the French Guiana Red List and 12 among the 17 species evaluated were classified as Data Deficient (IUCN France et al., 2017). In addition, two other species that are found in the territory are classified in the IUCN global Red List: the fin whale (Vulnerable) and the blue whale (Endangered). Hence, French Guiana bears a particular responsibility for the conservation of cetacean biodiversity but a lot remains to be done to strengthen knowledge and conservation of these species in the territory. The monitoring of the large pelagic megafauna covered by Mannocci et al. (2013) regular aerial surveys should be pursued as well as the in-progress program dedicated to Guiana dolphin in the coastal area. Opportunistic data collected during oil exploration surveys should be compiled and analyzed more deeply. Other offshore cetacean-dedicated campaigns should be conducted with a focus on threatened and migrating species (sperm whale and balaenopterids). Finally, cooperation should be developed with neighboring countries to conduct knowledgestrengthening programs at the scale of the Guianas and more urgently to work on a regional marine mammal response plan in case of an oil spill.

\section{Acknowledgments}

The authors would like to thank the French Guiana DEAL and the European Union that funded the OSL and GEPOG campaigns and the analyses presented in this paper, as well as TOTAL that allowed us to use $\mathrm{COHABYS}$ data. We are grateful to our technical partners: the Guyavoile, CREOCEAN, the Pelagis Observatory of La Rochelle University and the LIS laboratory of Toulon University for their expertise and support. Many thanks also to the members of our associations and the sailors for their deep involvement at each step of the project: Sandrine and Frédéric Lachot, Georges Grepin, Vikie Plaza-Lozano, Roselyne Viala, François Monier, Philippe Mendes, Ousseynou Diouf, Loïc Majellac.

\section{References}

Albouy, C., Delattre, V.L., Mérigot, B., Meynard, C.N. and Leprieur, F. (2017) Multifaceted biodiversity hotspots of marine mammals for conservation priorities. Diversity and Distributions 23(6): 615-626. https://doi.org/10.1111/ddi.12556

Bortolotto, G.A., Danilewicz, D., Andriolo, A., Secchi, E.R., and Zerbini, A.N. (2016) Whale, whale, everywhere: Increasing abundance of western South Atlantic humpback whales (Megaptera novaeangliae) in their wintering grounds. PLoS One 11(10): 1-17. https://doi.org/10.1371/journal.pone.0164596 da Silva, V.M.F., Fettuccia, D., Rodrigues, E.S., Edwards, H., Moreno, I.B., Moura, J.F., Wedekin, LL., Bazzalo, M., Emin-Lima, NR., Carmo, N.A.S., Siciliano, S. and Utreras, V.B. (2010) Report of the Working Group on Distribution, Habitat Characteristics and Preferences, and Group Size. Latin American Journal of Aquatic Mammals 8(1-2): 31-38.

http://dx.doi.org/10.5597/lajam00151

de Boer, M.N. (2015) Cetaceans observed in Suriname and adjacent waters. Latin American Journal of Aquatic Mammals 10(1): 2-19. http://dx.doi.org/10.5597/lajam00189

de Boer, M.N. and Willems, T. (2015) Observation of a humpback whale Megaptera novaeangliae with calf in the shallow coastal waters of Suriname. Academic Journal of Suriname 6: 1-8.

Froidefond J-M. (2012) Physique et chimie du milieu marin : Couleur des eaux. Pages 28-37 in Guiral, D. and Le Guen, R. (eds) Guyane Océane. Roger Le Guen, IRD, France.

Gillespie, D., Mellinger, D.K., Gordon, J., McLaren, D., Redmond., P., McHugh. R., Trinde, P., Deng, X-Y. and Thode, A. (2009) PAMGUARD: Semiautomated, open source software for realtime acoustic detection and localization of cetaceans. The Journal of the Acoustical Society of America 125(4): 2547-2547. https://doi.org/10.1121/1.4808713

Hu, C., Montgomery, E.T., Schmitt, R.W. and Muller-Karger, F.E. (2004) The dispersal of the Amazon and Orinoco River water in the tropical Atlantic and Caribbean Sea: Observation from space and S-PALACE floats. Deep-Sea Research Part II: Topical Studies in Oceanography 51 (special issue 10-11): 1151-1171. https://doi.org/10.1016/j.dsr2.2004.04.001

IUCN France, MNHN, GEPOG, Kwata, Biotope, Hydreco and OSL (2017) La Liste rouge des espèces menacées en France - Chapitres de la Faune vertébrée de Guyane. Paris, France. [Available from IUCN France, <uicn.fr>].

Kaschner, K., Tittensor, D.P., Ready, J., Gerrodette, T. and Worm, B. (2011). Current and future patterns of global marine mammal biodiversity. PLOS ONE 6(5).

https://doi.org/10.1371/journal.pone.0019653 
Lentz, S.J. (1995) Seasonal variations in the horizontal structure of the Amazon Plume inferred from historical hydrographic data. Journal of Geophysical Research 100: 2391-2400.

https://doi.org/10.1029/94JC01847

Longhurst, A.R. (2007) Ecological Geography of the Sea. Academic Press, Oxford, UK.

Mannocci, L., Monestiez, P., Bolaños-Jiménez, J., Dorémus, G., Jeremie, S., Laran, S., Rinaldi, R., Van Canneyt and O., Ridoux, V. (2013) Megavertebrate communities from two contrasting ecosystems in the western tropical Atlantic. Journal of Marine Systems 111-112: 208-222.

https://doi.org/10.1016/j.jmarsys.2012.11.002

Martinez, L., Geraldes, D., Suardi, A., Wyss, V., Dutrieux, E. and Chaineau, C.-H. (2019) New sightings records of marine mammals and seabirds off French Guiana. Latin American Journal of Aquatic Research 47(5): 753-763. https://scielo.conicyt. cl/scielo.php?pid=S0718-560X2019000500753\&script=sci_ arttext\&tlng=en

Moura, R.L., Amado-Filho, G.M., Moraes, F.C., Brasileiro, P.S., Salomon, P.S., Mahiques, M.M., Bastos, A.C., Almeida, M.G., Silva Jr., J.M., Araujo, B.F., Brito, F.P., Rangel, T.P., Oliveira, B.C.V., Bahia, R.G., Paranhos, R.P., Dias, R.J.S., Siegle, E., Figueiredo Jr, A.G., Pereira, R.C., Leal, C.V., Hajdu,E., Asp, N.E., Gregoracci, G.B., Neumann-Leitão, S., Yager, P.L., Francini-Filho, R.B., Fróes, A., Campeão, M., Silva, B.S., Moreira, A.P.B., Oliveira, L., Soares, A.C., Araujo, L., Oliveira, N.L., Teixeira, J.B., Valle, R.A.B., Thompson, C.C., Rezende, C.E., Thompson, F.L. (2016) An extensive reef system at the Amazon River mouth. Science Advances 2(4): e1501252. https://doi.org/10.1126/sciadv.1501252

Pompa, S., Ehrlich, P.R. and Ceballos, G. (2011) Global distribution and conservation of marine mammals. Proceedings of the National Academy of Sciences of the United States of America 108(33): 13600-13605.

https://doi.org/10.1073/pnas.1101525108

Ristau, N.G. (2012) Identificação molecular de mamíferos aquáticos provenientes de encalhes e de interações antrópicas no estado do Maranhão - Brasil. Undergraduate thesis. Maranhão State University (Universidade Estadual do Maranhão), São Luis, MA. 50 pp. [Available from PPGEAP, Universidade Federal do Pará, Brasil, <http://ppgeap.propesp.ufpa.br>]
Ristau, N.G., Martins, C.C.A., Luvizotto-Santos, R., Balensiefer, D., Sousa, G., Marmontel, M. and Farias, I.P. (2020) Sharing the space: Review of humpback whale occurrence in the Amazonian Equatorial Coast. Global Ecology and Conservation 22: e00854. https://doi.org/10.1016/j.gecco.2019.e00854

Roger, M., Cohen-Nabeiro, A., Lopez, R. and Kelle, L. (2016) Profil d'écosystème de la Guyane Française - Région Amazonie Européenne. Union Européenne Régions Ultra-pèriphériques et Pays et Territoires d'Outre-mer. BEST, contrat de service 07.0307.2013/666363/SER/B2, Commission Européenne. 167 pp. [Available from Best Initiative, European Commission, $<$ https://ec.europa.eu/environment/nature/biodiversity/best>].

Sebastiano, M., Bustamante, P., Eulaers, I., Malarvannan, G., Mendez-Fernandez, P., Churlaud, C., Blévin, P., Hauselmann, A., Covaci, A., Eens, M., Costantini, D. and Chastel, O. (2017) Trophic ecology drives contaminant concentrations within a tropical seabird community. Environmental Pollution 227: 183193. https://doi.org/10.1016/j.envpol.2017.04.040

Siciliano, S., Emin-Lima, N.R., Costa, A.F., Rodrigues, A.L.F., de Magalhães, F.A., Tosi, C.H., Garri, R.G., da Silva, C.R., de Sousa Jr, J.S. (2008) Revisão do conhecimento sobre os mamíferos aquáticos da costa norte do Brasil. Arquivos do Museu Nacional, Rio de Janeiro 66(2): 381-401.

https://repositorio.museu-goeldi.br/handle/mogeldi/229

Silva, C.R., Martins, A.C.M., Castro, I.J., Bernard, E., Cardoso, E.M., Lima, D.S., Gregorin, R., Rossi, R.V., Percequillo, A.R. and Castro., K.C. (2013) Mammals of Amapá State, Eastern Brazilian Amazonia: a revised taxonomic list with comments on species distributions. Mammalia 77(4): 409-424. https://doi.org/10.1515/mammalia-2012-0121

Smith, W.O. and Demaster, D.J. (1996) Phytoplankton biomass and productivity in the Amazon River plume: correlation with seasonal river discharge. Continental Shelf Research 16: 291319. https://doi.org/10.1016/0278-4343(95)00007-N

Ternon, J-F., and Guiral, D. (2012) Physique et chimie du milieu marin: Nature et richesse des eaux. Pages 38-46 in Guiral, D. and Le Guen, R. (eds) Guyane Océane. Roger Le Guen, IRD, France. 